Article

\title{
Young Chinese Consumers' Choice between Product-Related and Sustainable Cues-The Effects of Gender Differences and Consumer Innovativeness
}

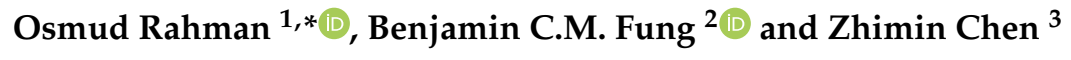 \\ 1 School of Fashion, Ryerson University, Toronto, ON M5B 2K3, Canada \\ 2 School of Information Studies, McGill University, Montreal, QC H3A 1X1, Canada; ben.fung@mcgill.ca \\ 3 Manchester Fashion Institute, Manchester Metropolitan University, Manchester M15 6BG, UK; \\ T.Chen@mmu.ac.uk \\ * Correspondence: orahman@ryerson.ca
}

Received: 6 April 2020; Accepted: 5 May 2020; Published: 7 May 2020

\begin{abstract}
Sustainability has received widespread attention in both academia and industry, but there is still a paucity of research investigating the relationships between gender, consumer innovativeness, and clothing, as well as how they may influence sustainable practices. The overarching objective of this study is to investigate clothing expenditure, product cues (intrinsic, extrinsic and sustainable), gender (men and women) and consumer innovativeness (fashion innovators and non-innovators) in China, in order to find out how these factors may influence consumers' choices. To address the research objective, 10 intrinsic cues, three extrinsic cues, and seven sustainable cues were used to investigate apparel consumers' choices and preferences. A self-administered online survey consisted of eight items on sustainable commitment and behaviour, six items of fashion innovativeness adapted from the Domain-Specific Innovativeness scale, 20 items concerning product cues, and numerous demographic and behaviour-related questions. In total, 1819 usable data were collected in China, including 614 males and 1196 females. The results revealed that four out of eleven hypotheses were supported, another four were partially supported, while the remainders were not. For example, both female consumers and fashion innovators relied more on style and colour to evaluate an apparel product than fashion non-innovators and male consumers. However, men tended to rely more on the brand name and country of origin to guide their product selection and purchases than women. In terms of the influence of sustainable cues, Chinese consumers are more concerned about the social/ethical cues than environmental cues. Interestingly, women were more concerned about "no animal skin use" in evaluating apparel products than men. All in all, the results of this study can provide valuable information and meaningful insight for fashion designers, product developers, and marketers to develop effective communication strategies to guide potential customers in understanding a plethora of apparel values, including functionality, aesthetics, finances, altruism, and sustainability.
\end{abstract}

Keywords: sustainability; sustainability practices; product attributes; sustainable clothing; gender; consumer innovativeness; young consumers; China; product evaluation; consumer choice

\section{Introduction}

Due to the launch of China's "one-child policy" in 1979, urban families were restricted to having only one child. As a result, singletons or "only children" received extra family attention and resources, and were often pampered or spoiled by their parents and grandparents, especially during their childhood. This phenomenon has been described as "six-pockets, one mouth" syndrome [1] or "4-2-1 indulgence" [2]. In other words, such children typically benefitted from six sources of disposable income-one from each of their parents and four more from their grandparents. In such a context, it is 
not difficult to understand why many Chinese young people now have a lot more money to spend on consumer goods and services than the preceding generations. According to many studies [3-5], this younger generation is also known as the "spoilt generation," "generation of spoilt 'little emperors'," “privileged generation" or "rich second generation" (富二代 fuerdai).

As people become more affluent, they do not necessarily search for a product merely based on its functional and monetary benefits, but also on its aesthetic, altruistic and ecological values. Several researchers [6-8] have pointed out that affluent individuals are not requires to focus on basic needs to survive, and thus, have more opportunity and greater freedom to search for products with intangible/added values (less materialistic/pragmatic), such as sustainable or recyclable products. Indeed, other than personal needs and conspicuous consumption, it has been shown that Chinese consumers are becoming increasingly aware of environmental issues and sustainable consumption. According to the Greendex survey carried out in 2014 [9], China scored 57.5 points in the overall green index at that time and was ranked in second place out of 18 countries. This study also reported that $65 \%$ of Chinese participants were highly concerned about environmental problems. In a similar vein, a study conducted by the China Chain Store and Franchise Association reported that more than $70 \%$ of Chinese consumers understood the concept of sustainable consumption [10]. Over the last two decades, the Chinese Government has stepped up its efforts to reduce the environmental impact of its industries by promoting sustainable production and consumption through various initiatives, such as the "Environmental Risk Management Initiative," "Greening the "Belt and Road' Initiative," and the development of sustainable zone in Shenzhen, Guilin, and Taiyuan [11]. "Sustainable future" and "harmonious society" (hexie shehui) are two of the key objectives of China's $13^{\text {th }}$ Five Year Plan (2016-2020) [10,12]. Other than the government initiatives, many scholars from a variety of disciplines have conducted a plethora of studies on sustainability to illuminate, explain, and address some of the current and ongoing issues in China, topics include energy conservation [13], sustainable consumption behaviours [14], eco-products [15], sustainable practices and transformable design [16], eco-labelling [17], zero-waste clothing design [18], recycling and upcycling [19], slow fashion movement [20], and circular economy [21]. It is evident that the issue of sustainability has received widespread attention in both academia and industry. Even so, there is still a paucity of research examining the relationships between genders, consumer innovativeness, and clothing and how they might influence sustainable practices. Therefore, the overarching objective of this study is to investigate clothing expenditure, product cue utilization, gender effects and consumer innovativeness in relation to sustainability in an emerging market-China.

\section{Literature Review}

\subsection{Product Cues Classifications and Typologies}

Sustainability can be described as a way "to protect the environment, use natural resources wisely and promote quality of life, while not spoiling the lives of future consumers" [22]. However, some scholars [23] have pointed out that "sustainability" cannot be defined in universal terms. It carries different or multiple meanings in different contexts, and the term "sustainability" has been used interchangeably with environmental/eco-friendly, green, ethical [24-26]. Currently, there is no universal agreement or clear consensus on how to define "sustainability" and "sustainable practices." In this study, sustainable purchasing behaviour refers to the behaviour of apparel shoppers who pay attention to environmental, social and ethical issues. In terms of environmental issues, energy efficiency and water usage are often considered as the two most important issues in sustainable production [27,28]. Another recent study conducted by the KPMG [29] also reported that consumers in Hong Kong, Shanghai and Tokyo tended to focus more on environmental concerns than people in New York and London. With these perspectives, it would be worthwhile and meaningful to investigate the relative importance of sustainable cues among many product-related ones, and the following question was raised to guide and direct the current research study: 
"Do sustainable cues attract enough attention from Chinese young consumers when they shop for apparel products?"

According to previous cue-utilization studies [30,31], consumers often use multiple product cues as surrogate indicators to guide their selection and purchasing decisions. To better understand how product cues may play a role in consumers' buying process, twenty apparel attributes were selected for the study. The selection criteria for these product cues were based on their relevance and frequency of use for apparel and sustainability research [32-35]. Apparel cues can be dichotomized into many different genres. For example, intrinsic and extrinsic, tangible and intangible, objective and subjective, psychic and physical, functional and aesthetic, product-related and production-related, or sustainable and non-sustainable [30,36-38]. Some of these concepts overlap or are similar. However, it is beyond the scope of this study to define and distinguish all these binary concepts. In this study, intrinsic and extrinsic cues were adopted. Intrinsic cues refer to the physical makeup or composition of a product, whereas extrinsic cues are product-related attributes but are not inherent to the product. Consumers are more likely to use extrinsic cues, such as price and brand name to guide their purchases if they are not familiar with the nature of the product itself. Extrinsic cues are relatively easy to process, interpret, and understand, whereas intrinsic cues involve judging the physical properties of a product, which requires technical/practical knowledge and evidence from earlier consuming experiences. According to Swam and Combs [38], intrinsic cues can be further divided into psychic/appearance cues and physical/performance cues, with psychic utility being associated with aesthetic and hedonic aspects of a product, such as style and colour, whereas physical utility is associated with functional and utilitarian aspects such as durability and comfort [39]. It is important to note that the "product attribute" and "product cue" are used interchangeably in this article. To address the research objective, 10 intrinsic cues, three extrinsic cues, and seven sustainable cues were used to investigate apparel consumers' choice and preferences (as shown in Table 1).

10 intrinsic cues including colour, style, durability, comfort, garment fit, fabric, quality, garment life, certified eco-label and certified ethical label. These product cues are directly related or attached to a physical product.

1. Three intrinsic cues without further classification-quality, fabric and fit

2. Two psychic or aesthetic cues-colour and style

3. Two physical or functional cues-comfort and durability

4. Three sustainable cues-garment life (longevity, recyclable, reusable), certified ethical label and certified eco-label

Three extrinsic cues including brand name, country of origin (COO) and price. These product cues are not directly related to the physical properties of a product.

Seven sustainable cues including less water usage, air quality, less energy usage, worker safety, fair wages, no child labour, and no animal skin use. These product cues relate to sustainable production and responsibilities in three main areas-environmental, social and ethical.

Many apparel studies $[31,33]$ revealed that consumers often use multiple cues not only to evaluate a product but also to justify the choices they made. However, there is still very limited empirical research that has examined the salient impact of intrinsic, extrinsic and sustainable cues on apparel purchases, particularly from the Chinese consumers' perspectives. 
Table 1. Product cues—categorizations and definitions astute.

\begin{tabular}{|c|c|c|}
\hline Product Cues & Types & Characteristics and Definitions \\
\hline \multicolumn{3}{|c|}{ Apparel product-related cues } \\
\hline Colour & Intrinsic-Psychic (In-Ps) & $\begin{array}{c}\text { Colour information (e.g., hue, value and intensity) is the most visible element for } \\
\text { apparel products [40]. }\end{array}$ \\
\hline Style & Intrinsic-Psychic (In-Ps) & Combination of design features within a garment [41]. \\
\hline Durability & Intrinsic-Physical (In-Ph) & Length of time a garment is suitable for use [42]. \\
\hline Comfort & Intrinsic-Physical (In-Ph) & Physical interactions and experiences with the clothing material [43]. \\
\hline Garment fit & Intrinsic (In) & $\begin{array}{c}\text { Sufficient room for movement, comfortable to wear, aesthetic appeal and } \\
\text { fashionability [44]. }\end{array}$ \\
\hline Fabric & Intrinsic (In) & $\begin{array}{c}\text { Fabric tactile properties, weight, and texture providing protection, aesthetic appearance } \\
\text { and physical comfort [45]. }\end{array}$ \\
\hline Quality (workmanship) & Intrinsic (In) & The ability of a garment to meet both functional and aesthetic expectations [46]. \\
\hline Garment life (longevity, recyclable, reusable) & Intrinsic-Sustainable (In-Su) & $\begin{array}{l}\text { Keeping end-of-life-cycle products from disposal through recycling and reuse if } \\
\text { possible [47]. }\end{array}$ \\
\hline Certified eco-friendly label & Intrinsic-Sustainable (In-Su) & Certified labels to inform consumers about the environmental impacts of products [48]. \\
\hline Certified ethical label (sweatshop-free) & Intrinsic-Sustainable (In-Su) & Certified label to inform consumers about ethical consumption [49]. \\
\hline Brand name & Extrinsic (Ex) & $\begin{array}{c}\text { Name, symbol, design, or mark used as a signal to communicate social status, wealth, } \\
\text { and group affiliation }[50,51] .\end{array}$ \\
\hline Country of origin (“Made-in” label) & Extrinsic (Ex) & $\begin{array}{c}\text { Country of origin (country-of-manufacture or assembly) influence consumers' } \\
\text { perception [52]. }\end{array}$ \\
\hline Price & Extrinsic (Ex) & Price is linked to financial and perceived risks or uncertainty [53]. \\
\hline \multicolumn{3}{|l|}{ Production-related cues } \\
\hline Less water usage & Sustainable-Environmental (Su-En) & Reduce or minimize the water usage for textile and apparel production [54]. \\
\hline Air quality & Sustainable-Environmental (Su-En) & Strive for "pollution-free" textile and clothing production [47]. \\
\hline Less energy usage & Sustainable-Environmental (Su-En) & Reduce or minimize the energy use for textile and apparel production $[54,55]$. \\
\hline Worker safety & Sustainable-social/ethical (Su-S/E) & Working conditions, health, and safety. \\
\hline Fair wages & Sustainable-social/ethical (Su-S/E) & Wages based on fair and reasonable market rates [56]. \\
\hline No child labour & Sustainable-social/ethical (Su-S/E) & Without the exploitation of children [57]. \\
\hline No animal skin use & Sustainable-social/ethical (Su-S/E) & Without the exploitation of animals [57]. \\
\hline
\end{tabular}




\subsection{Gender and Product Cues}

Previous empirical studies [58-60] found that gender plays a critical role in market segmentation. Marketing and consumer research [60-62] also reported that age, gender, and income are three of the most common demographic variables. As our targeted subjects were primarily recruited from the younger generation, the sample was quite homogeneous. Therefore, the current study was merely focused on gender effects rather than age and income.

There are differences in the way men and women think and behave when they shop for apparel products. Women are more interested in fashion and spend more time and mental energy on browsing and searching product information than men [60]. Previous studies [63-65] reported that women have more knowledge and experience in fashion consumption than men. Many female consumers can judge the overall quality of apparel products based on physical characteristics, such as garment fit, style, and fabric [45]. Thus, it would seem reasonable to suggest that women are less reliant on brand name and country of origin to guide their purchasing decisions than men. Interestingly, a study conducted in China [66] also revealed that buyers are more likely to use brand name and country of origin as surrogate indicators to guide their purchases, especially when they are less familiar with the product or lack the time to search for information. Therefore, the following hypothesis was proposed:

Hypothesis 1a. Chinese young male consumers rely more significantly on brand name and country of origin to evaluate apparel products than do their female counterparts.

According to Lee et al. [67], Asian women were more-highly concerned about their outward appearance and physical attractiveness than Asian men. Hence, it is not difficult to understand why Asian women are more interested in the aesthetic aspects (colour and style) of clothing than Asian men [68]. In general, women are more sensitive to aesthetic cues and can interpret the syntax of clothing codes better than men $[37,69]$. In contrast, men are relatively more interested in utilitarian aspects such as durability and comfort of clothing than women. Another study [70] also provides similar support, women pay more attention to the colour of textile products but less on the durability than men. In short, women are more focused on the aesthetic aspects of clothing (visual/sensorial attributes), whereas men are more concerned with the functional benefits (performance/utilitarian attributes). Thus, the following hypotheses were postulated.

Hypothesis $\mathbf{1 b}$. Chinese young female consumers rely more significantly on style and colour to evaluate apparel products than do their male counterparts.

Hypothesis 1c. Chinese young male consumers rely more significantly on durability and comfort to evaluate apparel products than do their female counterparts.

Moreover, a study [71] conducted in China reported that young female consumers were increasingly fashion conscious and willing to pay a higher price for fashionable products. According to Handa and Khare [72], female consumers tend to have higher involvement in fashion and spend more time and money on clothing, compared with their male counterparts. Another study [73] also indicated that women are more concerned about the intrinsic attributes but less sensitive to price. Based on these findings, the following hypothesis was proposed:

Hypothesis 1d. Chinese young male consumers rely more significantly on the product price to evaluate apparel products than their female counterparts.

Interestingly, prior studies [74,75] found that many consumers considered "green products" and "going green" as more feminine than masculine. According to a study [76] of gender differences in environmentalism, females displayed a greater commitment to the environment to mitigate the negative impact than males. In a similar vein, Austgulen et al. [70] found that women are more 
concerned about sustainable issues than men. Thus, it is not difficult to understand why women are generally more willing to purchase environmentally friendly products than men [77,78]. With such a perspective, the following hypothesis was formulated.

Hypothesis 2. Chinese young female consumers rely more significantly on sustainability cues to evaluate apparel products than do their male counterparts.

In terms of sustainable concerns, $69 \%$ of the participants expressed that the environmental impact did not affect their product choice and purchasing decision [70]. The KPMG [29] global survey indicated that a brand message of environmental issues was ranked relatively less significant, 13th out of 16 items. Moreover, some empirical studies [33,79-81] have reported that many consumers were not ready to sacrifice product benefits for the sake of making ethical purchases. As Iwanow et al. [82] pointed out, apparel purchases were often determined by price, quality and style, and price was considered particularly more significant than ethical attributes in their study. Many consumers are not willing to purchase sustainable products if the price is higher or if the quality is lower than the regular products [80].

Hypothesis 3. Both Chinese young female and male consumers rely more significantly on intrinsic cues to evaluate apparel products than sustainable cues.

\subsection{Consumer Innovativeness and Domain-Specific Innovativeness (DSI)}

Although gender differences can provide useful information to fashion practitioners and marketers on consumer profiling, gender alone is insufficient to fully elucidate the young consumers' buying motives in China. As previous research [83-85] has suggested, demographics alone cannot provide enough information about consumers. This may mean that external, proxy indicators of demographics such as age, may have less explanatory power in regards to clothing choice. Thus, we proposed that gender, consumer innovativeness, and product cues can generate more convincing evidence and meaningful insights regarding consumers' buying behaviour and preferences.

Consumer innovativeness is conceptualized as "the predisposition to buy new and different products and brands rather than remain with previous choices and consumption patterns" [86]. Rogers [87] defines innovativeness as "the degree to which an individual is relatively earlier in adopting new ideas than other members of his/her social system." There are three major approaches in consumer innovativeness-behavioural innovativeness, global innovativeness (personal trait), and domain-specific innovativeness (DSI) (product-specific). The behavioural innovativeness refers to those individuals who adopt new ideas, products, and services at an earlier or introductory stage. According to Rogers [87], adopters can be categorized into five groups: Innovators, early adopters, early majority, late majority, and laggards. However, this approach has been criticized by prior researchers $[88,89]$ because of several methodological shortcomings, such as limited generalizability to other contexts, reliability and validity cannot be assessed, and this "time-of-adoption" method cannot be used to predict future behaviour. As a result, some researchers [90,91] proposed global innovativeness-a "cross-sectional" approach as an alternative to "time-of-adoption." According to Goldsmith [92], the global characteristics of innovativeness can be considered as a personality trait reflecting a "willingness to try new things" or "willingness to change." In addition to the global innovativeness, DSI was also widely used by many researchers $[93,94]$ in different contexts. The DSI approach is often linked to broader innovative traits reflecting the tendency to adopt new products within a specific domain of interest. According to some studies [88,95], the measures of DSI scale are more reliable and predictive for the adoption of new products as compared to global innovativeness. In addition, many studies [39,96-98] demonstrated that the DSI scale was suitable for measuring consumer innovativeness in a specific product domain such as apparel. Therefore, the DSI was adopted for the current study. 


\subsection{Consumer Innovativeness and Product Cues}

Previous research has suggested that consumer innovativeness, in general, is a better indicator of product adoption than socio-demographics, such as gender, age, and income $[39,99,100]$. Fashion innovators are more interested in fashion and tend to spend more money on clothing than fashion non-innovators [39,101]. A study conducted in the United Kingdom [102] found that fashion innovators often relied on media and celebrities for fashion information, and also shopped more frequently and spent more money on clothing than non-innovators. Thus, the following hypothesis was propounded:

Hypothesis 4. Fashion innovators spend more money on apparel products than do fashion non-innovators in China.

Fashion innovators tended to pay more attention to aesthetic cues such as style and colour to create a fashionable look in the public [103]. On the contrary, many fashion non-innovators do not purchase new or cutting-edge clothing, particularly at the introductory stage. They tend to adopt new fashion styles only after they have become popular or widely accepted. Fashionability, aesthetic and trendiness are not the priorities for fashion non-innovators when they shop for clothing. As Workman and Studak [104] pointed out, fashion innovators approach fashion from a want-based perspective (hedonic motivation), while non-innovators approach fashion from a need-based perspective (utilitarian motivation). In other words, fashion innovators are more interested in the aesthetic and experiential values of a product whereas fashion non-innovators are more focused on instrumental and functional aspects. Based on the above discussion, the following hypotheses were formulated.

Hypothesis 5a. Fashion innovators rely more significantly on style and colour to evaluate apparel products than do fashion non-innovators in China.

Hypothesis $5 \mathbf{b}$. Fashion non-innovators rely more significantly on comfort and durability to evaluate apparel products than do fashion innovators in China.

As mentioned in the earlier section, consumer innovativeness plays a salient role in the adoption and acceptability of new products. Previous research also indicated that consumer innovativeness can be used as an important predictor in the early adoption of green/pro-environmental products and services [105]. In general, fashion innovators are more willing to act green and more receptive to new ideas than non-innovators [105,106]. For example, Persaud and Schillo [107] found that "consumers who strongly identify with environmental causes are more likely to perceive greater value in organic products; however, this effect is stronger for innovators compared to late adopters." Another study of consumer innovativeness [108] indicated that fashion leaders placed greater importance on social values. They often display higher social participation than non-innovators [109]. Thus, it is reasonable to suggest that fashion innovators are more concerned about the sustainable aspects of a product than non-innovators when they shop for clothing. With this perspective, the following hypotheses were proposed.

Hypothesis 6a. Fashion innovators rely more significantly on "production-related" sustainable attributes (3 Su-En and 4 Su-S/E cues) to evaluate apparel products than do fashion non-innovators in China.

Hypothesis 6b. Fashion innovators rely more significantly on "product-related" sustainable attributes (3 In-Su cues) to evaluate apparel products than do fashion non-innovators in China.

\section{Methodology}

A self-administered online questionnaire comprised of three sections was developed for the study. The first section covers two measuring instruments: Sustainable commitment and behaviour and 
consumer fashion innovativeness. Eight measuring items of sustainable commitment and behaviour, such as "when I have the choice between two equal clothing items, I purchase the one less harmful to others and the environment," and "I prefer to purchase eco-clothing, even if it is somewhat more expensive" were adopted from D'Souza [110], and 5-point Likert scale was used for the measurement. To measure the fashion innovativeness, six items were adopted from Goldsmith and Hofacker's [88] domain-specific innovativeness (DSI) scale. This scale consists of three positively worded and six negatively worded statements. The Domain-Specific Innovativeness (DSI) scale was employed to categorize participants into two consumer groups (fashion innovators and fashion non-innovators) by splitting the distribution of innovative scores, based on one standard deviation above the mean value suggested by Goldsmith and Flynn [111] and Goldsmith and Hofacker [88]. The DSI is a reliable and psychometrically sound instrument, which has been widely employed in different domains such as fashion [39,102], electronic products [112], video-on-demand and organic food [113]. The second section consisted of 20 items of product cues-13 apparel-related cues and seven production-related sustainable cues (as indicated in Table 1). Participants were asked to rate the importance of each cue based on a five-point Likert scale anchored from 1 as unimportant to five as very important. The selection criteria of these twenty product cues were based on the relevancy for clothing purchases, and also the frequency of use in previous fashion and sustainability research [32-35]. The last section contained demographic and behavioural questions asking participants to report their age, gender, income, level of education, and annual clothing expenditure.

The English version of the survey questionnaire was translated into Chinese and then back-translated into the original language. This back-translation method [114] was used to prepare the simplified Chinese version for use in the People's Republic of China. The survey was then pre-tested with 20 Chinese individuals to avoid any misunderstandings and inapplicable questions, and amendments were accordingly made to the questionnaire. An online data-gathering tool (Survey Monkey) was used for the current study. We chose web-based surveys over traditional paper surveys because this method provides convenience for participants, reduces financial costs, and minimizes coding time and errors [115]. The data were primarily collected from convenience sampling with the assistance of acquaintances and friends in China. The participants were primarily recruited from universities through email and WeChat in the first-tier cities, including Beijing, Shanghai, Guangzhou, and Shenzhen.

\section{Findings}

In total, 1819 usable data were collected. The sample consisted of $614(33.8 \%)$ males and $1196(65.8 \%)$ females. Gender balance was skewed toward females. This imbalanced gender ratio could be due to the fact that females are more interested and actively engaged in fashion than their male counterparts $[60,64,65]$. The vast majority of the participants were students $(n=1698,93.3 \%)$ aged between 18 and $24(n=1729,95.1 \%)$. As shown in Table 2, 73.5\% $(n=1337)$ received less than $¥ 40,000$ income/pocket money/allowance per year. Almost half of the participants spent $1-10 \%$ of their income on clothing annually.

\subsection{Environmental Commitment and Behaviour}

Prior to further analysis, Cronbach $\alpha$ was computed to test the internal consistency among all measuring items to ensure the general criterion was met. According to Nunnally and Bernstein [116], reliability coefficients of 0.70 or greater are considered to be "good." The results of Cronbach's alpha scores of all items were considered "very good" ranging from 0.863 to 0.885 . Moreover, all eight measuring items of "environmental commitment and behaviour" scored higher than the mean of 3.0 on a five-point scale across all data sets, as shown in Table 3. These findings indicated that the participants were committed to protecting the environment regardless of their gender and fashion innovativeness. Thus, it is reasonable to suggest that if the product information is available to the consumers, they are more likely to use multiple attributes, including sustainable cues to evaluate clothing, rather than merely focusing on a single product-related cue such as style or brand name. In the context of apparel 
shopping, it is evident that consumers often use various descriptive, inferential or informational cues to guide their product choice and purchasing decisions. As Liefeld and Wall [117] pointed out in their study, multi-cue design can bring the investigation closer to the realism of the consumer market. Thus, the inclusion of sustainable cues in this study was deemed to be important, particularly many participants reported that they were committed to protecting the environment.

Table 2. Demographic profile of participants.

\begin{tabular}{ccc}
\hline & $\mathbf{N}=\mathbf{1 8 1 9}$ & Percent \\
\hline Gender & & \\
Male & 614 & 33.8 \\
Female & 1196 & 65.8 \\
Other & 9 & 0.5 \\
Age & & \\
$18-24$ & 1729 & 95.1 \\
25 or above & 90 & 4.9 \\
Level of Education & & \\
High School & 141 & 7.8 \\
Undergraduate (Bachelor) & 1609 & 88.5 \\
Graduate (Master \& PhD) & 46 & 2.5 \\
Other & 23 & 1.3 \\
Less than ¥40,000 & & \\
$¥ 40,000-¥ 79,999$ & 1337 & 73.5 \\
$¥ 80,000-¥ 119,999$ & 204 & 11.2 \\
$¥ 120,000$ or above & 114 & 6.2 \\
Employment status & 164 & 9.0 \\
Student & & \\
Full-time employed & 1698 & 93.3 \\
Part-time employed & 60 & 3.3 \\
Other & 29 & 1.6 \\
Annual Income (include pocket moneyance) & 32 & 1.7 \\
1-10\% & & \\
11-20\% & 888 & 48.8 \\
More than 20\% & 622 & 34.2 \\
Annual spending on clothes (ot expenditure) & 309 & 16.9 \\
\hline
\end{tabular}

Although the majority of the participants were concerned about the environment, some participants tended to pay more attention to certain areas than others. For example, the $t$-test result indicated that there are statistically significant mean differences between fashion innovators and fashion non-innovators on all measuring items of environmental commitment and behaviour, except "I would avoid buying clothing items if it had potentially harmful environmental effects" ( $t=1.433, \mathrm{df}=1817$, $p=0.152)$ and "I prefer to purchase eco-clothing even if it is somewhat more expensive" $(t=0.854$, $\mathrm{df}=1817, p=0.393$ ). In terms of gender differences, there are no statistically significant mean differences between males and females on environmental commitment and behavior, except two measuring items "I would rather spend my money on eco-friendly clothes more than anything else" $(t=2.978, \mathrm{df}=1808$, $p=0.003)$ and "I prefer to purchase eco-clothing even if it is somewhat more expensive" $(t=3.108$, $\mathrm{df}=1808, p=0.002)$. Therefore, it seems reasonable to suggest that male consumers are willing to spend more money on eco-clothing than females. 
Table 3. Environmental commitment and behaviour: Significant mean differences between genders/consumer innovator groups.

\begin{tabular}{|c|c|c|c|c|c|c|c|c|c|c|c|c|c|c|}
\hline \multirow[b]{2}{*}{ Eco commitment and behaviour } & \multicolumn{2}{|c|}{$\begin{array}{c}\text { Males } \\
(n=614)\end{array}$} & \multicolumn{2}{|c|}{$\begin{array}{l}\text { Females } \\
(n=1196)\end{array}$} & \multirow[b]{2}{*}{$t$} & \multirow[b]{2}{*}{$\mathrm{df}$} & \multirow[b]{2}{*}{$p$} & \multicolumn{2}{|c|}{$\begin{array}{l}\text { Fashion Innovators } \\
\quad(n=233)\end{array}$} & \multicolumn{2}{|c|}{$\begin{array}{l}\text { Non-Innovators } \\
\quad(n=1596)\end{array}$} & \multirow[b]{2}{*}{$t$} & \multirow[b]{2}{*}{$\mathrm{df}$} & \multirow[b]{2}{*}{$p$} \\
\hline & M & SD & M & $\mathrm{SD}$ & & & & M & SD & $\mathrm{M}$ & SD & & & \\
\hline $\begin{array}{l}\text { Protecting the natural environment increases } \\
\text { my quality of life }\end{array}$ & 4.22 & 0.777 & 4.21 & 0.697 & 0.280 & 1808 & 0.779 & 4.33 & 0.707 & 4.19 & 0.730 & 2.632 & 1817 & 0.009 \\
\hline $\begin{array}{l}\text { Supporting environmental protection makes } \\
\text { me more committed to the environment }\end{array}$ & 4.18 & 0.764 & 4.18 & 0.642 & 0.032 & 1808 & 0.974 & 4.31 & 0.651 & 4.16 & 0.692 & 3.189 & 1817 & 0.001 \\
\hline $\begin{array}{l}\text { Supporting environmental protection makes } \\
\text { me more socially responsible }\end{array}$ & 4.15 & 0.801 & 4.15 & 0.691 & 0.096 & 1808 & 0.924 & 4.32 & 0.712 & 4.12 & 0.734 & 3.776 & 1817 & 0.000 \\
\hline $\begin{array}{l}\text { When I have the choice between two equal } \\
\text { clothing items, I purchase the one less } \\
\text { harmful to others and the environment }\end{array}$ & 4.16 & 0.824 & 4.11 & 0.734 & 1.405 & 1808 & 0.160 & 4.26 & 0.769 & 4.10 & 0.769 & 2.978 & 1817 & 0.003 \\
\hline $\begin{array}{l}\text { I would avoid buying clothing items if it had } \\
\text { potentially harmful environmental effects }\end{array}$ & 4.10 & 0.818 & 4.08 & 0.703 & 0.608 & 1808 & 0.543 & 4.24 & 0.713 & 4.06 & 0.749 & 3.476 & 1817 & 0.001 \\
\hline $\begin{array}{l}\text { I would be willing to reduce my consumption } \\
\text { to help protect the environment }\end{array}$ & 3.95 & 0.839 & 3.93 & 0.756 & 0.509 & 1808 & 0.611 & 4.00 & 0.822 & 3.92 & 0.784 & 1.433 & 1817 & 0.152 \\
\hline $\begin{array}{l}\text { I would rather spend my money on } \\
\text { eco-friendly clothes more than anything else }\end{array}$ & 3.97 & 0.817 & 3.85 & 0.769 & 2.978 & 1808 & 0.003 & 4.00 & 0.846 & 3.88 & 0.782 & 2.127 & 1817 & 0.034 \\
\hline $\begin{array}{l}\text { I prefer to purchase eco-clothing even if it is } \\
\text { somewhat more expensive }\end{array}$ & 3.52 & 0.947 & 3.38 & 0.835 & 3.108 & 1808 & 0.002 & 3.48 & 0.948 & 3.42 & 0.869 & 0.854 & 1817 & 0.393 \\
\hline
\end{tabular}

$p<0.05$ (indicated in bold type). 


\subsection{Intrinsic and Extrinsic Cues-Genders}

According to the $t$-test analysis (see Table 4), there were statistically significant mean differences in brand name $(t=4.240, \mathrm{df}=1722, p=0.000)$ and $\mathrm{COO}(t=3.002, \mathrm{df}=1722, p=0.003)$ being used as salient evaluative cues between males and females. It is obvious that male consumers relied a lot more on brand name and COO than female consumers when they shop for apparel products. These findings are consistent with a previous study [66], and Hypothesis 1a. was supported. The result of the $t$-test scores also indicated that there were statistically significant mean differences in style $(t=-4.423, \mathrm{df}=1722, p=0.000)$ and colour $(t=-2.824, \mathrm{df}=1722, p=0.007)$ being used as salient evaluative cues between males and females. These findings revealed that females more relied on style and colour to guide their apparel selection and purchases than men. Thus, Hypothesis $1 \mathrm{~b}$. was supported. In terms of intrinsic/physical cues, there were significant differences in both durability $(t=-3.128, \mathrm{df}=1723, p=0.002)$ and comfort $(t=-2.098, \mathrm{df}=1723, p=0.036)$ being used as salient evaluative cues between genders. However, females have a statistically significantly higher mean score on comfort $\left(\bar{x}_{\text {female }}=4.453, \bar{x}_{\text {male }}=4.384\right)$ but less on durability $\left(\bar{x}_{\text {female }}=3.894, \bar{x}_{\text {male }}=4.029\right)$ than men. Therefore, Hypothesis 1c. was partially supported. A plausible explanation for this result may lie in the fact that women relied more on the tactile input and stimulation to judge a garment than men. This explanation is supported by past literature $[45,118]$. Regarding the price being used as salient evaluative cues, there was no statistically significant mean difference between males and females, therefore Hypothesis 1d was not supported.

Table 4. The significant difference of evaluative cues between males and females - mean scores, standard deviation and $t$-test.

\begin{tabular}{|c|c|c|c|c|c|c|c|c|}
\hline \multirow{2}{*}{$\begin{array}{c}\text { Product Cues } \\
\text { Apparel product-related cues }\end{array}$} & \multicolumn{2}{|c|}{$\begin{array}{c}\text { Male } \\
(n=614)\end{array}$} & \multicolumn{2}{|c|}{$\begin{array}{c}\text { Female } \\
(n=1196)\end{array}$} & \multirow[b]{2}{*}{ 95\% CI for Mean Difference } & \multirow[b]{2}{*}{$t$} & \multirow[b]{2}{*}{$\mathrm{df}$} & \multirow[b]{2}{*}{$p$} \\
\hline & $M$ & $S D$ & $M$ & $S D$ & & & & \\
\hline Quality (workmanship) & 4.348 & 0.7173 & 4.345 & 0.7173 & $-0.0802,0.0864$ & 0.073 & 1723 & 0.942 \\
\hline Fit & 4.283 & 0.7899 & 4.393 & 0.6758 & $-0.1815,-0.0386$ & -3.021 & 1723 & 0.003 \\
\hline Certified ethical label & 4.121 & 0.9062 & 4.170 & 0.8305 & $-0.1346,0.0363$ & -1.129 & 1723 & 0.259 \\
\hline Price & 4.068 & 0.8433 & 4.067 & 0.7621 & $-0.0772,0.0805$ & 0.041 & 1722 & 0.967 \\
\hline Durability & 4.029 & 0.8756 & 3.894 & 0.8375 & $0.0504,0.2201$ & 3.128 & 1723 & 0.002 \\
\hline Garment life & 3.997 & 0.8894 & 3.909 & 0.7846 & $0.0059,0.1699$ & 2.103 & 1722 & 0.005 \\
\hline Colour & 3.947 & 0.8693 & 4.063 & 0.7761 & $-0.1999,-0.0325$ & -2.824 & 1722 & 0.007 \\
\hline Certified eco-label & 3.910 & 0.9302 & 3.861 & 0.8489 & $-0.0392,0.1358$ & 1.082 & 1723 & 0.279 \\
\hline Brand & 3.376 & 1.0479 & 3.166 & 0.9344 & $0.1129,0.3073$ & 4.240 & 1722 & 0.000 \\
\hline No child labour & 4.067 & 0.9414 & 4.062 & 0.8377 & $-0.0830,0.0914$ & 0.095 & 1723 & 0.924 \\
\hline Fair wages & 4.046 & 0.8650 & 4.004 & 0.7854 & $-0.0385,0.1237$ & 1.029 & 1723 & 0.303 \\
\hline No animal skin use & 4.003 & 0.9766 & 4.155 & 0.8791 & $-0.2430,-0.0609$ & -3.272 & 1723 & 0.001 \\
\hline Air quality & 3.916 & 0.9272 & 3.807 & 0.9539 & $0.0153,0.2038$ & 2.280 & 1723 & 0.023 \\
\hline Less energy usage & 3.874 & 0.9343 & 3.815 & 0.8031 & $-0.0258,0.1437$ & 1.365 & 1723 & 0.172 \\
\hline Less water usage & 3.606 & 0.9625 & 3.482 & 0.8573 & $0.0346,0.2130$ & 2.723 & 1723 & 0.007 \\
\hline
\end{tabular}

\subsection{Sustainable Cues-Genders}

In terms of the sustainable cues, the $t$-test scores indicated that there were statistically significant mean differences in four sustainable cues out of ten (3 In-Su cues; 3 Su-En cues and 4 Su-S/E cues) being used as salient evaluative cues between genders, including "garment life" $(t=2.103, \mathrm{df}=1722$, $p=0.005)$, "no animal skin use" $(t=-3.272, \mathrm{df}=1723, p=0.001)$, "air quality" $(t=2.280, \mathrm{df}=1723$, $p=0.023)$ and "less water usage" $(t=2.723, \mathrm{df}=1723, p=0.007)$. As indicated in Table 4 , males have statistically significantly higher mean scores on the aforementioned items except "no animal skin use $\left(\bar{x}_{\text {male }}=4.003, \bar{x}_{\text {female }}=4.115\right)$. The findings only revealed that female consumers relied more 
significantly on only one sustainable cue ("no animal skin use") to evaluate apparel products than do their male counterparts. Therefore, Hypothesis 2 . was partially supported.

As indicated in Table 5, the participants rated "comfort" as the most important cue, followed by "fit," "quality" and "style." It seems these four intrinsic cues played a more significant role in clothing evaluation than many other product cues. However, our findings did not confirm that all intrinsic cues were rated higher than all the sustainable cues. For example, the mean scores of "certified ethical label," and "worker safety," were rated higher than "fabric," "colour" and "durability." As shown in Table 6, the result of Pearson's correlation coefficient indicated that the top six product cues were strongly correlated at 0.01 level. To check the significant difference between intrinsic cues and sustainable cues, paired samples $t$-tests were conducted. For example, "style" and "certified ethical label" as well as "worker safety" and "fabric" were computed for empirical testing. The results revealed that the Chinese young consumers considered "style" $(\overline{\mathrm{x}}=4.22, \mathrm{SD}=0.739)$ more significant compared to "certified ethical label" $(\overline{\mathrm{x}}=4.16, \mathrm{SD}=0.739), t(1818)=2.999, p=0.003$; and "worker safety" $(\overline{\mathrm{x}}=4.14$, $\mathrm{SD}=0.754)$ more significant than "colour" $(\overline{\mathrm{x}}=4.03, \mathrm{SD}=0.815), t(1818)=4.833, p=0.000$. It is evident that not all intrinsic cues were considered more important than sustainable cues. Thus, Hypothesis 3. was partially supported.

Moreover, many participants rated "brand name" and "country of origin" as the two least-important apparel evaluative cues. These findings are similar to those of previous apparel studies $[37,60,119]$. As shown in Table 5, the results also revealed that the participants tended to rely more on the social and ethical cues (certified ethical label, worker safety, no child labour, no animal skin use, and fair wages) to guide their clothing purchases than environmental cues (certified eco-label, garment life, air quality, less energy use, less water use). With this perspective, it would seem reasonable to suggest that young Chinese consumers are more concerned about the social/ethical attributes than environmental and symbolic (brand name and country of origin/“made-in” label) attributes.

Table 5. Descriptive analysis of product cues-frequency, mean and standard deviation.

\begin{tabular}{ccc}
\hline Product Cues & \multicolumn{2}{c}{ Sample } \\
\hline & $M$ & $S D$ \\
\hline Comfort & 4.43 & 0.647 \\
Fit & 4.36 & 0.714 \\
Quality (workmanship) & 4.33 & 0.672 \\
Style & 4.22 & 0.739 \\
Certified ethical label & 4.16 & 0.855 \\
Worker safety & 4.14 & 0.805 \\
Fabric & 4.12 & 0.754 \\
No animal skin use & 4.10 & 0.914 \\
Price & 4.07 & 0.795 \\
No child labour & 4.07 & 0.878 \\
Colour & 4.03 & 0.815 \\
Fair wages & 4.03 & 0.816 \\
Durability & 3.95 & 0.850 \\
Garment life & 3.95 & 0.829 \\
Certified eco-label & 3.88 & 0.879 \\
Air quality & 3.84 & 0.880 \\
Less energy usage & 3.84 & 0.849 \\
Less water usage & 3.53 & 0.895 \\
Country of origin & 3.25 & 1.055 \\
Brand name & 3.23 & 0.983 \\
\hline
\end{tabular}


Table 6. Descriptive and correlation analysis of the top six product evaluative cues.

\begin{tabular}{ccccccc}
\hline Product Cues & Comfort & Fit & Quality & Style & $\begin{array}{c}\text { Certified } \\
\text { Ethical Label }\end{array}$ & $\begin{array}{c}\text { Worker } \\
\text { Safety }\end{array}$ \\
\hline Min-max & $1-5$ & $1-5$ & $1-5$ & $1-5$ & $1-5$ & $1-5$ \\
Median & 5 & 4 & 4 & 4 & 4 & 4 \\
Frequency & 1819 & 1819 & 1819 & 1819 & 1819 & 1819 \\
Mean & 4.43 & 4.36 & 4.33 & 4.22 & 4.16 & 4.14 \\
SD & 0.647 & 0.714 & 0.672 & 0.739 & 0.855 & 0.805 \\
Comfort (In-Ph) & 1 & $0.537 *$ & $0.607 *$ & $0.428^{*}$ & $0.368^{*}$ & $0.346^{*}$ \\
Fit (In) & & 1 & $0.394^{*}$ & $0.379 *$ & $0.279 *$ & $0.250^{*}$ \\
Quality (In) & & & 1 & $0.452^{*}$ & $0.431^{*}$ & $0.339^{*}$ \\
Style (In-Ps) & & & & 1 & $0.302 *$ & $0.232^{*}$ \\
Certified ethical label (In-Su) & & & & & & 1 \\
Worker safety (Su-S/E) & & & & & & $0.386^{*}$ \\
\hline
\end{tabular}

* Correlation is significant at the 0.01 level.

\subsection{Other Findings and Observations-Genders}

The $t$-test analysis also indicated that there were statistically significant mean differences in comfort $(t=-2.098, \mathrm{df}=1723, p=0.036)$, fit $(t=-3.021, \mathrm{df}=1723, p=0.003)$ and style $(t=-4.423$, $\mathrm{df}=1722, p=0.000$ ) being used as salient evaluative cues between males and females. Other than the psychic/aesthetic cues (style and colour), female participants also relied a lot more on comfort, fit and style to enhance their product selection than the male participants. However, men were more concerned about the garment life than their female counterparts. The mean difference in garment life ( $t=2.103, \mathrm{df}=1722, p=0.005)$ being used as evaluative cue between genders was significant. This could be the reasons why there were significant mean differences in, "I would rather spend my money on eco-friendly clothes more than anything else," "I prefer to purchase eco-clothing even if it is somewhat more expensive" (see Table 3) and "durability" (see Table 4) between genders. It seems reasonable to suggest that men are willing to spend more money on eco-clothing for garment life (longevity/reuse/recycle) and durability than women.

\subsection{Consumer Innovativeness}

As a result, 224 participants $(12.3 \%)$ of the sample were classified as fashion innovators, while the remaining 1596 participants $(87.7 \%)$ were classified as fashion non-innovators. The distribution of fashion innovators and non-innovators is similar to Hansen and Hansen's [120] study-13\% of their sample were designated as innovators. According to the findings, $74 \%$ of fashion innovators versus $48 \%$ of non-innovators spent more than $10 \%$ of their income on clothing annually. As indicated in Table 7, a large number of fashion innovators (34.1\%) were willing to spend more than $20 \%$ of their income on clothing than non-innovators (14.6\%). Thus, these results provide support for Hypothesis 4 .

Table 7. Fashion innovators and non-innovators-annual spending on apparel products.

\begin{tabular}{ccccc}
\hline Expenditure on Apparel Products & $\begin{array}{c}\text { Fashion Innovators } \\
(\mathbf{N}=\mathbf{2 2 3})\end{array}$ & $\begin{array}{c}\text { Fashion Non-Innovators } \\
(\mathbf{N}=\mathbf{1 5 9 6})\end{array}$ \\
\hline $\begin{array}{c}\text { Annual spending on apparel products (\% of their } \\
\text { income including pocket money/allowance) }\end{array}$ & $\mathrm{n}$ & $\%$ & $\mathrm{n}$ & $\%$ \\
\hline $1-10 \%$ & 58 & 26.0 & 830 & 52.0 \\
$11-20 \%$ & 89 & 39.9 & 533 & 33.4 \\
More than 20\% & 76 & 34.1 & 233 & 14.6 \\
\hline
\end{tabular}

\subsection{Consumer Innovativeness and Product Cues}

According to the $t$-test results, there were statistically significant mean differences in style $(t=7.664$, $\mathrm{df}=1817, p=0.000)$ and colour $(t=4.823, \mathrm{df}=1817, p=0.000)$ being used as salient evaluative cues 
between fashion innovators and non-innovators. Fashion innovators relied more significantly on both, style and colour to evaluate apparel products than non-innovators. This finding is consistent with Law et al.'s [103] study, and Hypothesis 5a was supported. Regarding comfort and durability, $t$-test results indicated that there was statistically significant mean difference in comfort $(t=3.160$, $\mathrm{df}=1817, p=0.002)$ but not durability $(t=0.590, \mathrm{df}=1817, p=0.556)$ being used as salient evaluative cues between fashion innovators and non-innovators. Surprisingly, fashion innovators relied more on comfort to evaluate clothing than non-innovators. The possible explanation is that fashion innovators rely more on "Need-for Touch" (NFT) or tactile feeling than non-innovators. Therefore, Hypothesis 5 b was not supported. As shown in Table 8, the results also revealed that there were no statistically significant mean differences in "production-related" sustainable cues being used as salient evaluative cues between fashion innovators and non-innovators. Therefore, Hypothesis 6a was not supported. In terms of the impact of "product-related" sustainable attributes, there were no statistically significant mean differences in "garment life" and "certified eco-label" cues being used as salient evaluative cues between fashion innovators and non-innovators, except "certified ethical label" $(t=2.162, \mathrm{df}=1817$, $p=0.031$ ). Based on these findings, Hypothesis $6 \mathrm{~b}$ was partially supported.

To sum up, four hypotheses were supported, three were not supported and four were partially supported, as reported in Table 9.

Table 8. The significant difference of evaluative cues between fashion innovators and non-innovators-mean scores, standard deviation and $t$-test.

\begin{tabular}{|c|c|c|c|c|c|c|c|c|}
\hline \multirow[t]{2}{*}{ Product Cues } & \multicolumn{2}{|c|}{$\begin{array}{l}\text { Fashion } \\
\text { Innovators }\end{array}$} & \multicolumn{2}{|c|}{$\begin{array}{c}\text { Fashion } \\
\text { Non-Innovators }\end{array}$} & \multirow[b]{2}{*}{$\begin{array}{l}\text { 95\% CI for Mean } \\
\text { Difference }\end{array}$} & \multirow[b]{2}{*}{$t$} & \multirow[b]{2}{*}{$\mathrm{df}$} & \multirow[b]{2}{*}{$p$} \\
\hline & $M$ & $S D$ & $M$ & $S D$ & & & & \\
\hline \multicolumn{9}{|l|}{ Apparel product-related cues } \\
\hline Style & 4.57 & 0.624 & 4.18 & 0.741 & $0.297,0.501$ & 7.664 & 1817 & 0.000 \\
\hline Comfort & 4.56 & 0.573 & 4.41 & 0.655 & $0.055,0.236$ & 3.160 & 1817 & 0.002 \\
\hline Fit & 4.49 & 0.629 & 4.34 & 0.723 & $0.046,0.245$ & 2.856 & 1817 & 0.004 \\
\hline Quality (workmanship) & 4.47 & 0.656 & 4.31 & 0.673 & $0.064,0.252$ & 3.287 & 1817 & 0.001 \\
\hline Colour & 4.27 & 0.754 & 3.99 & 0.817 & $0.166,0.393$ & 4.823 & 1817 & 0.000 \\
\hline Certified ethical label & 4.27 & 0.828 & 4.14 & 0.857 & $0.012,0.252$ & 2.162 & 1817 & 0.031 \\
\hline Fibre/material & 4.24 & 0.784 & 4.11 & 0.749 & $0.023,0.234$ & 2.388 & 1817 & 0.017 \\
\hline Price & 4.17 & 0.813 & 4.06 & 0.792 & $-0.006,0.217$ & 1.862 & 1817 & 0.063 \\
\hline Durability & 3.98 & 0.872 & 3.94 & 0.847 & $-0.083,0.155$ & 0.590 & 1817 & 0.556 \\
\hline Certified eco-label & 3.91 & 0.959 & 3.88 & 0.868 & $-0.091,0.155$ & 0.507 & 1817 & 0.612 \\
\hline Garment life & 3.87 & 0.885 & 3.96 & 0.821 & $-0.207,0.025$ & -1.541 & 1817 & 0.124 \\
\hline Brand name & 3.34 & 0.995 & 3.22 & 0.981 & $-0.021,0.254$ & 1.656 & 1817 & 0.098 \\
\hline Country of origin & 3.13 & 1.120 & 3.26 & 1.045 & $-0.285,0.011$ & -1.817 & 1817 & 0.069 \\
\hline \multicolumn{9}{|l|}{ Apparel production-related cues } \\
\hline Worker safety & 4.17 & 0.804 & 4.14 & 0.806 & $-0.082,0.144$ & 0.533 & 1817 & 0.594 \\
\hline No animal skin usage & 4.16 & 0.934 & 4.10 & 0.912 & $-0.068,0.188$ & 0.915 & 1817 & 0.360 \\
\hline No child labour & 4.13 & 0.899 & 4.06 & 0.875 & $-0.049,0.197$ & 1.174 & 1817 & 0.241 \\
\hline Fair wages & 4.07 & 0.851 & 4.01 & 0.811 & $-0.056,0.172$ & 0.993 & 1817 & 0.321 \\
\hline Less energy usage & 3.90 & 0.895 & 3.83 & 0.843 & $-0.050,0.188$ & 1.131 & 1817 & 0.258 \\
\hline Air quality & 3.90 & 0.985 & 3.84 & 0.868 & $-0.064,0.183$ & 0.950 & 1817 & 0.342 \\
\hline Less water usage & 3.49 & 0.963 & 3.54 & 0.885 & $-0.174,0.077$ & -0.763 & 1817 & 0.446 \\
\hline
\end{tabular}


Table 9. Hypothesis testing summary.

\begin{tabular}{|c|c|c|}
\hline Hypothesis & Description & Result \\
\hline Hypothesis 1a. & $\begin{array}{c}\text { Chinese young male consumers rely more significantly on brand } \\
\text { name and country of origin (COO) to evaluate apparel products } \\
\text { than do their female counterparts }\end{array}$ & Supported \\
\hline Hypothesis $1 b$. & $\begin{array}{l}\text { Chinese young female consumers rely more significantly on style } \\
\text { and colour to evaluate apparel products than do their } \\
\text { male counterparts }\end{array}$ & Supported \\
\hline Hypothesis 1c. & $\begin{array}{c}\text { Chinese young male consumers rely more significantly on } \\
\text { durability and comfort to evaluate apparel products than do their } \\
\text { female counterparts }\end{array}$ & Partially supported \\
\hline Hypothesis $1 \mathrm{~d}$. & $\begin{array}{l}\text { Chinese young male consumers rely more significantly on price to } \\
\text { evaluate apparel products than do their female counterparts }\end{array}$ & Not supported \\
\hline Hypothesis 2. & $\begin{array}{c}\text { Chinese young female consumers rely more significantly on } \\
\text { sustainable cues to evaluate apparel products than do their } \\
\text { male counterparts. }\end{array}$ & Partially supported \\
\hline Hypothesis 3. & $\begin{array}{c}\text { Both Chinese young female and male consumers rely more } \\
\text { significantly on intrinsic cues to evaluate apparel products than } \\
\text { sustainable cues. }\end{array}$ & Partially supported \\
\hline Hypothesis 4 . & $\begin{array}{l}\text { Fashion innovators spend more money on apparel products than do } \\
\text { fashion non-innovators in China. }\end{array}$ & Supported \\
\hline Hypothesis 5a. & $\begin{array}{l}\text { Fashion innovators rely more significantly on style and colour to } \\
\text { evaluate apparel products than do fashion non-innovators in China } \\
\text { Fashion non-innovators rely more significantly on comfort and }\end{array}$ & Supported \\
\hline Hypothesis $5 b$. & $\begin{array}{l}\text { durability to evaluate apparel products than do fashion innovators } \\
\text { in China }\end{array}$ & Not supported \\
\hline Hypothesis 6a. & $\begin{array}{l}\text { Fashion innovators rely more significantly on "production-related" } \\
\text { sustainable attributes ( } 3 \mathrm{Su}-\mathrm{En} \text { and } 4 \mathrm{Su}-\mathrm{S} / \mathrm{E} \text { cues) to evaluate } \\
\text { apparel products than do fashion non-innovators in China. }\end{array}$ & Not supported \\
\hline Hypothesis $6 b$. & $\begin{array}{c}\text { Fashion innovators rely more significantly on "product-related" } \\
\text { sustainable attributes ( } 3 \text { In-Su cues) to evaluate apparel products } \\
\text { than do fashion non-innovators in China. }\end{array}$ & Partially supported \\
\hline
\end{tabular}

\section{Conclusions-Implications and Recommendations}

\subsection{Extrinsic Cues_Brand Name and Country of Origin are More Important Cues for Men}

Although brand name and country of origin were viewed as the two least important product cues, male consumers relied more significantly on these two attributes than their female counterparts. The possible explanation is that male consumers are less sensitive to fashion and unfamiliar with clothing properties. Thus, it could be a challenge for them to judge, compare and select a better product among many similar alternatives. Therefore, brand name and country of origin can be served as a proxy variable or quick surrogate indicator to guide their purchasing decisions and justify their choice. These findings concur with that of previous research $[66,121,122]$ on the effects of brand name and country of origin. For example, Maheswaran [122] reveals that if the consumers are not familiar with a product, they tend to use the country's image (or brand image) as a "halo effect" in the product selection and evaluation. Although brand name and country of origin did not play an important role in apparel evaluation as compared to other product cues, fashion practitioners and marketers should not ignore these two attributes. These product cues can be very useful when consumers are not motivated to think about or have no time to search for product information. In other words, brand name and country of origin can reduce a consumer's shopping effort by conveying a bundle of product values and associative meanings (e.g. innovative and fashionable design, high-quality and reliable product) to the buyers. People can use them as a heuristic basis for evaluation, particularly for new and innovative products. 


\subsection{Intrinsic Cues—Style, Colour, Comfort, and Fit are More Important for Females}

According to the results, young Chinese female consumers relied more heavily on style and colour to evaluate apparel products than men. Apart from these two attributes, female consumers were also more concerned about fit and comfort than men. These findings underpin several implications for fashion practitioners and academicians. First of all, it would seem reasonable to suggest that female consumers use aesthetic cues such as style and colour to express themselves, (re)construct their identity, accentuate their desirable body parts, and conform to the fashionable norm. Secondly, young women may encounter more challenges and difficulties in finding well-fitting and fashionable styles than their male counterparts. Thus, many of them paid extra attention to both garment fit and style. Thirdly, style, comfort, and fit were cited as significant evaluative cues because they are closely related. For example, changing the garment fit (e.g., from loose-fitting to form-fitting) will greatly affect the style (e.g., silhouette and aesthetic appeal) and physical comfort (tactile experience and ease of movement). Therefore, apparel designers should not over-emphasize or merely focus on a single cue or a monolithic feature of a product, e.g., "atomistic approach" through the improvement of a single attribute. Rather, they should focus on multiple cues and the tripartite relationship of style, comfort and fit when they design an apparel product, e.g., "holistic approach" through the integration of multiple attributes. Fourth, if the aesthetic aspects cannot be met or fulfilled, consumers may not even consider other attributes, such as durability, country of origin, environmental friendliness and social/ethical responsibilities. It is imperative for fashion practitioners to help young people to understand that eco-clothing or domestic-made apparels can be attractive and fashionable as well. We believe that the aforementioned implications can provide practical information and empirical evidence to both fashion practitioners and researchers. In order to create a desirable product with a better adoption rate, fashion designers and product developers should focus on multiple aspects of a product such as the aesthetic, experiential, functional and psychological attributes [123]. Ultimately, if a new product can meet users' needs and aspirations, people are more likely to keep the product for a longer time and use it more frequently. As a result, the product can be better utilized, and its lifespan can be prolonged. As Zafarmand et al. [124] assert, " ... a product's aesthetic durability promotes its sustainability." Thus, "aesthetic longevity" design is an important sustainable concept.

\subsection{Intrinsic and Sustainable Cues-Durability and Sustainability are More Important for Men}

Interestingly, the present study found that male consumers are more concerned about durability than females. One possible explanation is that men are less interested in fashion and spend less time searching and shopping for clothes. In such a context, it is reasonable to suggest that male consumers are more willing to purchase a durable and/or sustainable product that can last for a longer time. It seems other findings reveal similar evidence and empirical support for this viewpoint. For example, the $t$-test scores indicated that there were statistically significant mean differences in "garment life" $(t=2.103, \mathrm{df}=1722, p=0.005)$ being used as salient evaluative cues between genders. In addition, male consumers are willing to spend more money on eco-clothing than females (as indicated in Table 3) - “I would rather spend my money on eco-friendly clothes more than anything else" $(t=2.978$, $\mathrm{df}=1808, p=0.003)$ and "I prefer to purchase eco-clothing even if it is somewhat more expensive" $(t=3.108, \mathrm{df}=1808, p=0.002)$. Based on the results and preceding discussion, the fashion practitioners must focus on both functional and aesthetic longevity to enhance the attractiveness and prolong the lifespan of a product. Sustainable clothing will not be widely accepted if essential and specific needs are not met.

\subsection{Significance of Sustainable Cues-Gender Differences}

In terms of sustainable cues for apparel evaluation, females consumers considered "no animal skin use" more important than male consumers. This finding suggests that fashion designers should stop or avoid using fur and animal skins for their products, including clothing, footwear, and accessories. 
In many cases, "cruelty-free" products (clothing and cosmetics) do not only attract the right consumers but also help to build a stronger brand image. Interestingly, our findings indicated that Chinese young men were more concerned about the environmental aspects including "air quality," "less water usage" and "garment life" than Chinese females. In light of these findings, it would seem reasonable to suggest that environmental issues play a critical role in men's clothing evaluation and consumption. In order to promote sustainable fashion and lifestyle, companies should feature their eco-products in both printed and digital media such as LOHAS (乐活 Lifestyle of Health and Sustainability) magazine. According to a report published by KPMG [125], “digital content, social media, celebrities, and fashion influencers" can capture millennials' attention and exert great influence on their consumption behaviour. Thus, it is reasonable to assume that, through collaboration with fashion influencers, bloggers, and celebrities (e.g., 龙宽 Long Kuan, Chinese pop star and vegan activist), a sustainable lifestyle can be promoted and communicated more effectively, particularly among the younger demographics.

\subsection{Fashion Innovators and Non-Innovators-Apparel Spending}

The results indicate that fashion innovators spent more money on apparel products than fashion non-innovators. This finding yielded clear support for previous research [93,101,102]. This finding underscores at least two important implications. First of all, fashion innovators are willing to spend more money on new products and fashion styles than non-innovators. Relatively, they are more venturesome, and not afraid to try out new ideas and products. Hence, fashion companies should seize the opportunity since fashion innovators are willing to take risks when purchasing new products, including new and sustainable fashion. Secondly, many fashion innovators also act as opinion leaders. They can spread favourable word-of-mouth of a new product to later buyers if they are satisfied with its design and sustainable features. As Wiedmann et al. [126] pointed out in their study, fashion leaders are often comprised of fashion super-spreaders, narrative fashion experts, and helpful friends. As such, it is imperative for fashion practitioners to truly focus on "green" production and sustainable practices with substantive actions rather than so-called 'greenwashing'.

\subsection{Intrinsic Cues-Style and Colour}

The result of this study indicated that fashion innovators relied more significantly on both style and colour to evaluate apparel products than the non-innovators. Interestingly, these findings are in line with the females' responses. This may be due to the fact that many fashion innovators are females, as reported in previous research studies [101,104]. According to the collected data, there were $7 \%$ of men out of the male sample $(n=614)$ and $14.8 \%$ of women out of the female sample $(n=1196)$ were fashion innovators. It is not difficult to understand why many female fashion innovators also cited both style and colour were salient evaluative cues. Therefore, fashion practitioners and marketers should pay extra attention to these two aesthetic attributes.

\section{7. "Production-Related" Sustainable Cues}

In terms of sustainable cues, there are some useful implications for Chinese fashion designers, product developers, and marketers. According to the results, fashion innovators relied more significantly on "production-related" sustainable cues (environmental, social/ethical) to evaluate apparel products than the fashion non-innovators. These findings are not in support of earlier literature $[93,127,128]$, and raise at least two questions: How can the fashion practitioners integrate, improve and communicate the "production-related" cues through design and production? How can the fashion practitioners convey sustainable information to the buyers including the fashion non-innovators? To address these questions, fashion practitioners may need to re-examine/-evaluate the product design processes and production methods, as well as the supply chain system to reduce energy consumption and water usage, improve working conditions and air quality, and offer fair wages and "sweatshop-free" products. To gain the consumers' trust, fashion companies should reveal and disclose more sustainable information (e.g., working conditions and wages) to the public through various means such as 
products (ethical/eco-label), annual report, company web site, and printed and digital media. Many social media tools can be used in China to inform young consumers about the sustainable concept and practices, such as WeChat (微信), Sina Weibo (新浪微博), Little Red Book (小红书 Xiaohongshu), WeChat Official Account (微信公众平台), Tik Tok (抖音), and Taobao Live Streaming (淘宝网上直播). For example, many online influencers such as bloggers, "Kols" (key opinion leaders), online stars (网红 wanghong) [129] can exert a strong influence on fashion consumption, particularly among the young people.

To summarize, on the practical side, the results of the current study can provide valuable information and meaningful insights to the fashion designers, product developers, and marketers to develop effective communication strategies to better assist potential customers in understanding a wider range of apparel values, including functional, aesthetic, financial, altruistic and ecological. On the theoretical side, the results of this study provide evidence of the value that young Chinese people place on sustainable attributes when consumers shop for apparel and the effects of gender and innovativeness in relation to apparel evaluation with multiple cues in a rapidly changing market-China.

\section{Future Research}

Although the results provide meaningful information and insights on apparel selection and evaluation, further research of sustainability is needed, particularly in emerging and transitional economies. Moreover, there are some limitations to the present study. Firstly, the use of young Chinese consumers limits the generalizability of the results. Thus, fashion practitioners and marketers should be cautious in interpretation and application because the results presented here should not be generalized to other generational cohorts and socio-cultural contexts. Secondly, apparel was the only product employed for empirical testing and the results cannot be generalized to fit all consumer products. Thirdly, further research might employ different methods and approaches, such as ethnography, eye-tracking technologies, longitudinal research, and mixed methods research, which can shed additional light on this topic such as the change of consumers' preferences and buying behviour over a period of time and/or in different contexts. Fourthly, a comparative study of online and offline eco-clothing evaluation across different generational cohorts or countries could be interesting. Finally, to gain a deeper understanding of consumers' purchasing behaviour, it is worthwhile to further examine other possible apparel cues, such as wardrobe coordination and versatility (e.g., ability to transform).

Author Contributions: Conceptualization, O.R., B.C.M.F. and Z.C.; methodology, O.R. and B.C.M.F.; software, O.R.; validation, O.R. and B.C.M.F.; formal analysis, O.R., B.C.M.F. and Z.C.; investigation, O.R., B.C.M.F. and Z.C.; resources, O.R.; data curation, O.R. and Z.C.; writing-original draft preparation, O.R.; writing-review and editing, O.R. and Z.C.; visualization, O.R.; supervision, O.R.; project administration, O.R. All authors have read and agreed to the published version of the manuscript.

Funding: This research received no external funding.

Conflicts of Interest: The authors declare no conflict of interest.

\section{References}

1. Goll, S. Marketing China's (only) children get the royal treatment. Wall Street J. 1995, 8, B1.

2. Shao, A.T.; Herbig, P. Marketing implications of China's Little Emperors. Rev. Bus. 1994, 16, 16-20.

3. Lora-Wainwright, A. Fatness and well-being: Bodies and the generation gap in contemporary China. In The Body in Asia. Asia Pacific Studies; Turner, B.S., Zheng, Y., Eds.; Berghahn Books: New York, NY, USA, 2009; Volume 3, pp. 113-128.

4. Rahman, O.; Chen, X.; Au, R. Consumer behaviour of Chinese pre-teen and teenage youth. J. Glob. Fash. Mark. 2013, 4, 247-265. [CrossRef]

5. Spark, J. How China's "Spoiled" Second Generation Rich Help Their Parents' Businesses. Jing Daily, 6 February 2018. Available online: https://jingdaily.com/why-chinas-billionaire-class-arent-all-buildingbusiness-dynasties/ (accessed on 4 April 2020). 
6. De Mooij, M. Convergence and divergence in consumer behavior: Implications for global advertising. Int. J. Advert. 2003, 22, 183-202. [CrossRef]

7. Kemmelmeier, M.; Król, G.; Kim, Y.H. Values, economics, and proenvironmental attitudes in 22 societies. Cross Cult. Res. 2002, 36, 256-285. [CrossRef]

8. Maslow, A.H. A Theory of Human Motivation; Merchant Books: Dublin, Ireland, 2013.

9. GlobeScan. Greendex 2014: Consumer Choice and the Environment-A Worldwide Tracking Survey. GlobeScan, September 2014, pp. 1-20. Available online: https://globescan.com/wp-content/uploads/2017/07/Greendex_ 2014_Highlights_Report_NationalGeographic_GlobeScan.pdf (accessed on 4 April 2020).

10. China Daily. Over 70 Percent of Chinese Consumers Aware of Sustainable Consumption. China Daily, 23 August 2017. Available online: http://www.chinadaily.com.cn/business/2017-08/23/content_31009090.htm (accessed on 4 April 2020).

11. Song, S. Here's how China is Going Green. World Economic Forum, 26 April 2018. Available online: https: //www.weforum.org/agenda/2018/04/china-is-going-green-here-s-how (accessed on 4 April 2020).

12. Potts, J.; Runnalls, D. Sustainable Development and China: Recommendations for the Forestry, Cotton and E-products. International Institute for Sustainable Development, December 2008. Available online: https: //www.iisd.org/sites/default/files/publications/china_sd_sum_0.pdf (accessed on 4 April 2020).

13. Zhang, B.; Wang, Z.; Lai, K.H. Mediating effect of managers' environmental concern: Bridge between external pressures and firms' practices of energy conservation in China. J. Environ. Psychol. 2015, 43, $203-215$. [CrossRef]

14. Wang, P.; Liu, Q.; Qi, Y. Factors influencing sustainable consumption behaviours: A survey of the rural residents in China. J. Clean. Prod. 2014, 63, 152-165. [CrossRef]

15. Ip, Y.K. The marketability of eco-products in China's affluent cities. Manag. Environ. Qual. 2003, 14, 577-589. [CrossRef]

16. Rahman, O.; Gong, M. Sustainable practices and transformable fashion design-Chinese professional and consumer perspectives. Int. J. Fash. Des. Technol. Educ. 2016, 9, 233-247. [CrossRef]

17. Liu, Q.; Yan, Z.; Zhou, J. Consumer choices and motives for eco-labeled products in China: An empirical analysis based on the choice experiment. Sustainability 2017, 9, 331. [CrossRef]

18. Chiu, F.T. A study in elderly fashion and zero waste clothing design. In Proceedings of the International Conference on Human-Computer Interaction, Orlando area, FL, USA, 26-28 July 2019; pp. 427-438.

19. Paras, M.K.; Curteza, A. Revisiting upcycling phenomenon: A concept in clothing industry. Res. J. Text. Apparel. 2018, 22, 46-58. [CrossRef]

20. Zhang, Y.Z. Rational return-slow fashion in China. Spec. Zone Econ. 2014, 12, 83.

21. Yuan, Z.; Bi, J.; Moriguichi, Y. The circular economy: A new development strategy in China. J. Ind. Ecol. 2006, 10, 4-8. [CrossRef]

22. Yates, L. Green expectations. Consumer Focus, 2009. Available online: www.consumerfocus.org.uk/en/content/ cms/Publications_Repor/Publications_Repor.aspx (accessed on 4 April 2020).

23. Costanza, R.; Patten, B.C. Commentary: Defining and predicting sustainability. Ecol. Econ. 1995, 15, $193-196$. [CrossRef]

24. Carey, L.; Cervellon, M.C. Ethical fashion dimensions: Pictorial and auditory depictions through three cultural perspectives. J. Fash. Mark. Manag. Int. J. 2014, 18, 483-506. [CrossRef]

25. Chu, A.; Rahman, O. Colour, clothing, and the concept of 'green': Colour trend analysis and professionals' perspectives. J. Glob. Fash. Mark. 2012, 3, 147-157. [CrossRef]

26. Newholm, T.; Shaw, D. Studying the ethical consumer: A review of research. J. Consum. Behav. 2007, 6, 253-270. [CrossRef]

27. Allwood, J.; Laursen, S.E.; Malvido de Rodriguez, C.; Bocken, N. Well Dressed? The Present and Future Sustainability of Clothing and Textiles in the United Kingdom; Institute of Manufacturing, University of Cambridge: Cambridge, UK, 2006.

28. Hill, J.; Lee, H.-H. Young generation Y consumers' perceptions of sustainability in the apparel industry. J. Fash. Mark. Manag. Int. J. 2017, 16, 477-491. [CrossRef]

29. KPMG. Sustainable Fashion: A Survey on Global Perspectives. KPMG, January 2019. Available online: https://assets.kpmg/content/dam/kpmg/cn/pdf/en/2019/01/sustainable-fashion.pdf (accessed on 4 April 2020).

30. Hines, J.D.; Swinker, M.E. Knowledge: A variable in evaluating clothing quality. Int. J. Consum. Stud. 2001, 25, 72-76. [CrossRef] 
31. Rahman, O. Denim jeans: A qualitative study of product cues, body type and appropriateness of use. Fash. Pract. 2015, 7, 53-74.

32. Domina, T.; Koch, K. Environmental profiles of female apparel shoppers in the Midwest, USA. J. Consum. Stud. Home Econ. 1998, 22, 147-161. [CrossRef]

33. Jegethesan, K.; Sneddon, J.N.; Soutar, G.N. Young Australian consumers' preferences for fashion apparel attributes. J. Fash. Mark. Manag. 2012, 16, 275-289. [CrossRef]

34. Rahman, O. Understanding consumers' perceptions and behaviour: Implications for denim jeans design. J. Text. Appar. Technol. Manag. 2011, 7, 1-16.

35. Swinker, M.E.; Hines, J.D. Understanding consumers' perception of clothing quality: A multidimensional approach. Int. J. Consum. Stud. 2006, 30, 218-223. [CrossRef]

36. Rahman, O.; Zhu, X.; Liu, W.-S. A study of the pyjamas purchasing behaviour of Chinese consumers in Hangzhou, China. J. Fash. Mark. Manag. Int. J. 2008, 12, 217-231. [CrossRef]

37. Rahman, O.; Jiang, Y.; Liu, W.-S. Evaluative criteria of denim jeans: A cross-national study of functional and aesthetic aspects. Des. J. 2010, 13, 291-311. [CrossRef]

38. Swan, J.E.; Combs, L.J. Product performance and consumer satisfaction: A new concept. J. Mark. 1976, 40, 25-33. [CrossRef]

39. Rahman, O.; Chen, Z.; Fung, B.C.M.; Kharb, D. A cross-national study of consumer behaviour, innovativeness and apparel evaluation: China and India. J. Text. Inst. 2020, 111, 334-344. [CrossRef]

40. Rasband, J. Art Essentials in Color; Fairchild: New York, NY, USA, 2001.

41. Kunz, G.I. Merchandising: Theory, Principles, and Practice; Fairchild: New York, NY, USA, 1998.

42. Rosenau, J.A.; Wilson, D.L. Apparel Merchandising: The Line Starts Here, 2nd ed.; Fairchild Publications: New York, NY, USA, 2006.

43. Metje, N.; Sterling, M.C.J.; Baker, C.J. Pedestrian comfort using clothing values and body temperatures. J. Wind. Eng. Ind. Aerodyn. 2008, 96, 412-435. [CrossRef]

44. Stamper, A.A.; Sharp, S.H.; Donnel, L.B. Evaluating Apparel Quality, 2nd ed.; Fairchild: New York, NY, USA, 1991.

45. Rahman, $\mathrm{O}$. The influence of visual and tactile inputs on denim jeans evaluation. Int. J. Des. 2012, 6, 11-25.

46. O'Neal, G.; Hines, J.; Jackson, H. Interpreting the meaning of consumer perceptions of clothing quality. In Proceedings of the 1990 Annual Meeting, Uppsala, Sweden, 13-17 August 1990; Monument CO: Association of College Professors of Textiles and Clothing.

47. Fletcher, K. Sustainable Fashion and Textiles: Design Journeys; Earthscan: London, UK, 2008.

48. Bratt, C.; Hallstedt, S.; Robert, K.; Broman, G.; Oldmark, J. Assessment of ecolabelling criteria development from a strategic sustainability perspective. J. Clean. Prod. 2011, 19, 1631-1638. [CrossRef]

49. Carrigan, M.; Szmigin, I.; Wright, J. Shopping for a better world? An interpretive study of the potential for ethical consumption within the older market. J. Consum. Mark. 2004, 21, 401-417. [CrossRef]

50. Kolter, P. Marketing Management Analysis, Planning, Implementation and Control; Prentice-Hall: Upper Saddle River, NJ, USA, 1997.

51. Rahman, O.; Petroff, L. Communicating brand image through fashion designers' homes, flagship stores and ready-to-wear collection. In Global Fashion Brands: Style, Luxury \& History; Hancocks, J.H., II, Manlow, V., Muratovski, G., Peirson-Smith, A., Eds.; Intellect Publisher: Bristol, UK., 2014; pp. 179-198.

52. Lee, D.; Schaninger, C. Country of production/assembly as a new country image construct: A conceptual application to global transplant decision. Adv. Int. Mark. 1996, 7, 233-254.

53. Agarwal, S.; Teas, R. Perceived value: Mediating role of perceived risk. J. Mark. Theory Pract. 2001, 9, 1-14. [CrossRef]

54. Merchant, B. How Many Gallons of Water Does it Take to Make Treehugger, 14 June 2009. Available online: https://www.treehugger.com/clean-technology/how-many-gallons-of-water-does-it-take-to-make. html (accessed on 4 April 2020).

55. WWF. The Impact of a Cotton T-shirt. World Wildlife Fund (WWF), 16 January 2013. Available online: https://www.worldwildlife.org/stories/the-impact-of-a-cotton-t-shirt (accessed on 4 April 2020).

56. Fair Trade. 2015. Available online: http://www.fairtrade.org.uk/en/ehat-is-fairtrade (accessed on 4 April 2020).

57. Gandhi, M.; Kaushik, N. Socially responsive consumption behaviour-an Indian perspective. Soc. Responsib. J. 2016, 12, 85-102. [CrossRef] 
58. Cleveland, M.; Papadopoulos, N.; Laroche, M. Identity, demographics, and consumer behaviours: International market segmentation across product categories. Int. Mark. Rev. 2011, 28, 244-266. [CrossRef]

59. Do Paço, A.M.F.; Raposo, M.L.B.; Filho, W.L. Identifying the green consumer: A segmentation study. J. Target. Meas. Anal. Mark. 2009, 17, 17-25. [CrossRef]

60. Rahman, O.; Fung, B.C.M.; Chen, Z.; Chang, W.-L.; Gao, X. A study of apparel consumer behavior in China and Taiwan. Int. J. Fash. Des. Technol. Educ. 2018, 11, 22-33. [CrossRef]

61. Khare, A.; Mishra, A.; Parveen, C. Influence of collective self-esteem on fashion clothing involvement among Indian women. J. Fash. Mark. Manag. 2012, 16, 42-63. [CrossRef]

62. Wedel, M.; Kamakura, W.A. Market Segmentation: Conceptual and Methodological Foundations; Kluwer Academic Publishers: Boston, MA, USA, 1999.

63. Gitimu, P.N.; Work, J.; Robinson, J.R. Garment quality evaluation: Influence of fashion leadership, fashion involvement, and gender. Int. J. Fash. Des. Technol. Educ. 2013, 6, 173-180. [CrossRef]

64. Gupta, S.; Gentry, J.W. Construction of gender roles in perceived scarce environments-Maintaining masculinity when shopping for fast fashion apparel. J. Consum. Behav. 2016, 15, 251-260. [CrossRef]

65. Seock, Y.; Bailey, L. The influence of college students' shopping orientations and gender differences on online information searches and purchase behaviours. Int. J. Consum. Stud. 2008, 32, 113-121. [CrossRef]

66. Klein, J.G.; Ettenson, R.; Morris, M.D. The animosity model of foreign product purchase: An empirical test in the People's Republic of China. J. Mark. 1998, 62, 89-100. [CrossRef]

67. Lee, E.; Park, N.-K.; Han, J.H. Gender difference in environmental attitude and behaviors in adoption of energy-efficient lighting at home. J. Sustain. Dev. 2013, 6, 38-50. [CrossRef]

68. Creusen, M.E.H. The importance of product aspects in choice: The influence of demographic characteristics. J. Consum. Mark. 2010, 27, 26-34. [CrossRef]

69. McCracken, G.; Roth, V. Does clothing have a code? Empirical findings and theoretical implications in the study of clothing as a means of communication. Int. J. Res. Mark. 1989, 6, 13-33. [CrossRef]

70. Austgulen, M.H.; Stø, E.; Jatkar, A. The dualism of eco-labels in the global textile market. An Integrated Indian and European Perspective, Research Paper of Collaborative Project between CUTS International and SIFO. 2013. Available online: http://www.global-standard.org/media/com_acymailing/upload/ecolabels_2013_paper_ _es_194.pdf (accessed on 4 April 2020).

71. Lee, J.S.Y.; Yau, O.H.M.; Chow, R.P.M.; Sin, L.Y.M.; Tse, A.C.B. Changing roles and values of female consumers in China. Bus. Horiz. 2004, 47, 17-22. [CrossRef]

72. Handa, M.; Khare, A. Gender as a moderator of the relationship between materialism and fashion clothing involvement among Indian youth. Int. J. Consum. Stud. 2013, 37, 112-120. [CrossRef]

73. Dickson, M.A.; Sharron, J.L.; Catherine, O.M.; Dong, S.; Li, Z. Chinese consumer market segments for foreign apparel products. J. Consum. Mark. 2004, 21, 301-317. [CrossRef]

74. Bennett, G.; Williams, F. Mainstream Green: Moving Sustainability from Niche to Normal. 2011. Available online: http://assets.ogilvy.com/truffles_email/ogilvyearth/Mainstream_Green.pdf (accessed on 4 April 2020).

75. Brough, A.R.; Wilkie, J.E.B.; Ma, J.; Isaac, M.S.; Gal, D. Is eco-friendly unmanly? The green-feminine stereotype and its effect on sustainable consumption. J. Consum. Res. 2016, 43, 567-582. [CrossRef]

76. Zelezny, L.C.; Chua, P.-P.; Aldrich, C. Elaborating on gender differences in environmentalism. J. Soc. Issues 2000, 56, 443-458. [CrossRef]

77. Khan, N.; Trivedi, P. Gender differences and sustainable consumption behavior. Br. J. Mark. Stud. 2015, 3, 29-35.

78. Bulut, Z.A.; Çimrin, F.K.; Doğan, O. Gender, generation and sustainable consumption: Exploring the behavior of consumers from Izmir, Turkey. Int. J. Consum. Stud. 2017, 41, 597-604. [CrossRef]

79. Auger, P.; Devinney, T.M. Do what consumers say matter? The misalignment of references with unconstrained ethical intentions. J. Bus. Ethics. 2007, 76, 361-383. [CrossRef]

80. Carrigan, M.; Attalla, A. The myth of the ethical consumer-Do ethics matter in purchase behaviour? J. Consum. Mark. 2001, 18, 560-578. [CrossRef]

81. North, E.; De Vos, R.; Kotze, T. The importance of apparel product attributes for female buyers. J. Fam. Ecol. Consum. Serv. 2010, 31, 41-51. [CrossRef]

82. Iwanow, H.; McEachern, M.G.; Jeffrey, A. The influence of ethical trading policies on consumer apparel purchase decisions. Int. J. Retail. Distrib. Manag. 2005, 33, 371-387. [CrossRef] 
83. D'Souza, C.; Taghian, M.; Lamb, P.; Peretiatko, R. Green decisions: Demographics and consumer understanding of environmental labels. Int. J. Consum. Stud. 2007, 31, 371-376. [CrossRef]

84. Narang, R. Psychographic segmentation of youth in the evolving Indian retail market. Int. Rev. Retail. Distrib. Consum. Res. 2010, 20, 535-557. [CrossRef]

85. Rahman, O.; Chang, W.-T. Understanding Taiwanese female baby boomers through their perceptions of clothing and appearance. Fash. Pract. 2018, 10, 53-77. [CrossRef]

86. Im, S.; Mason, C.H.; Houston, M.B. Does innate consumer innovativeness related to new products/service adoption behaviour? The intervening role of social learning via vicarious innovativeness. J. Acad. Mark. Sci. 2007, 35, 63-75. [CrossRef]

87. Rogers, E.M. Diffusion of Innovations, 4th ed.; The Free Press: New York, NY, USA, 1995; p. 22.

88. Goldsmith, R.E.; Hofacker, C.F. Measuring Consumer Innovativeness. J. Acad. Mark. Sci. 1991, 19, $209-221$. [CrossRef]

89. Uray, N.; Dedeoglu, A. Identifying fashion clothing innovators by self-report method. J. Euromark. 1997, 6, 27-46. [CrossRef]

90. Hurt, H.T.; Joseph, K.; Cook, C.D. Scales for the measurement of innovativeness. Hum. Commun. Res. 1977, 4, 58-65. [CrossRef]

91. Midgley, D.F.; Dowling, G.R. Innovativeness: The concept and its measurement. J. Consum. Res. 1978, 4, 229-242. [CrossRef]

92. Goldsmith, R.E. The validity of scale to measure global innovativeness. J. Appl. Bus. Res. (JABR) 1991, 7, 89-97. [CrossRef]

93. Rahman, O.; Kharb, D. Fashion innovativeness in India: Shopping behaviour, clothing evaluation and fashion information sources. Int. J. Fash. Des. Technol. Educ. 2018, 11, 287-298. [CrossRef]

94. Venkatraman, M.P.; Price, L.L. Differentiating between cognitive and sensory innovativeness. J. Bus. Res. 1990, 20, 293-315. [CrossRef]

95. Citrin, A.V.; Sprott, D.E.; Silverman, S.N.; Stem, D.E., Jr. Adoption of internet shopping: The role of consumer innovativeness. Ind. Manag. Data Syst. 2000, 100, 294-300. [CrossRef]

96. Chakrabarti, S.; Baisya, R. The influences of consumer innovativeness and consumer evaluation attributes in the purchase of fashionable ethnic wear in India. Int. J. Consum. Stud. 2009, 33, 706-714. [CrossRef]

97. Handa, M.; Gupta, N. Gender influence on the innovativeness of young urban Indian online shoppers. J. Bus. Perspect. 2009, 13, 25-32. [CrossRef]

98. Klink, R.R.; Athaide, G.A. Consumer innovativeness and the use of new versus extended brand names for new products. J. Prod. Innov. Manag. 2010, 27, 23-32. [CrossRef]

99. Agarwal, R.; Prasad, J. The role of innovation characteristics and perceived voluntariness in the acceptance of information technologies. Decis. Sci. 1997, 28, 557-582. [CrossRef]

100. Jansson, J. Consumer eco-innovation adoption: Assessing attitudinal factors and perceived product characteristics. Bus. Strat. Environ. 2011, 20, 192-210. [CrossRef]

101. Quigley, C.J., Jr.; Notarantonio, E.M. A cross-cultural comparison of United States and Austrian fashion consumers. J. Euromark. 2009, 18, 233-244. [CrossRef]

102. Birtwistle, G.; Moore, C.M. Fashion innovativeness in the UK: A replication study. In Proceedings of the ANZMAC 2016 Conference Proceedings, Park City, UT, USA, 27-30 September 2006.

103. Law, K.M.; Zhang, Z.M.; Leung, C.S. Clothing deprivation, clothing satisfaction, fashion leadership and Hong Kong young consumers. J. Fash. Mark. Manag. Int. J. 2000, 4, 289-302. [CrossRef]

104. Workman, J.E.; Studak, C.M. Fashion consumers and fashion problem recognition style. Int. J. Consum. Stud. 2006, 30, 75-84. [CrossRef]

105. Thøgersen, J.; Haugaard, P.; Olesen, A. Consumer responses to ecolabels. Int. J. Consum. Stud. 2010, 11-12, 1787-1810.

106. Englis, B.G.; Phillips, D.M. Does innovativeness drive environmentally conscious consumer behaviour? Psychol. Mark. 2013, 30, 160-172. [CrossRef]

107. Persaud, A.; Schillo, S.R. Purchasing organic products: Role of social context and consumer innovativeness. Mark. Intell. Plan. 2017, 35, 130-146. [CrossRef]

108. Goldsmith, R.; Stith, M. The social values of fashion innovators. J. Appl. Bus. Res. 1993, 9, 10-17. [CrossRef] 
109. Chowdhary, U. Are fashion opinion leaders different from fashion nonleaders. In American Home Economics Association Annual Meeting Research Abstracts; Gritzmacher, J.E., Lovingood, R.P., Eds.; Meridian Education: Bloomington, IL, USA, 1988; p. 45.

110. D'Souza, C.; Gilmore, A.J.; Hartmann, P.; Ibáñez, V.A.; Sullivan-Mort, G. Male eco-fashion: A Market reality. Int. J. Consum. Stud. 2015, 39, 35-42. [CrossRef]

111. Goldsmith, R.E.; Flynn, L.R. The domain specific innovativeness scale: Theoretical and practical dimensions. In Association of Marketing Theory and Practice Proceedings; Moore, D.L., Ed.; D.L. Moore: Tonawanda, NY, USA, 1995; Volume 4, pp. 177-182.

112. Lim, H.; Park, J.-S. The effects of national culture and cosmopolitanism on consumers' adoption of innovation: A cross-cultural comparison. J. Int. Consum. Mark. 2013, 25, 16-28. [CrossRef]

113. Bartels, J.; Reinders, M.J. Social identification, social representations, and consumer innovativeness in an organic food context: A cross-national comparison. Food Qual. Prefer. 2010, 21, 347-352. [CrossRef]

114. Brislin, R.W. The wording and translation of research instruments. In Field Methods in Cross-cultural Research: Cross-cultural Research Methodology Series; Lonner, W.J., Berry, J.W., Eds.; Sage: Thousand Oaks, CA, USA, 1986; pp. 137-164.

115. Kang, J.; Park-Poaps, H. Hedonic and utilitarian shopping motivations of fashion leadership. J. Fash. Mark. Manag. Int. J. 2010, 14, 312-328. [CrossRef]

116. Nunnally, J.C.; Bernstein, I.H. Psychometric Theory, 3rd ed.; McGraw-Hill: New York, NY, USA, 1994.

117. Liefeld, J.; Wall, M. The effects of intrinsic, country-of-origin and price cues on product evaluation and choice. In E-European Advances in Consumer Research; Van Raaij, W.F., Bamossy, G.J., Provo, U.T., Eds.; Association for Consumer Research: San Diego, CA, USA, 1993; pp. 191-197.

118. Citrin, A.V.; Stem, D.E.; Spangenberg, E.R.; Clark, M.J. Consumer need for tactile input: An internet retailing challenge. J. Bus. Res. 2003, 56, 915-922. [CrossRef]

119. Chae, M.-H.; Black, C.; Heitmeyer, J. Pre-purchase and post-purchase satisfaction and fashion involvement of female tennis wear consumers. Int. J. Consum. Stud. 2006, 30, 25-33. [CrossRef]

120. Hansen, F.; Hansen, M. Children as innovators and opinion leaders. Young Consum. 2005, 1, 44-59. [CrossRef]

121. Kwang, J.N.; Holland, R.; Shackleton, J.; Hwang, Y.-Y.; Melewar, T.C. The effect of evaluation criteria on design attributes and brand equity in the product evaluation process. Brand Manag. 2008, 16, 195-212.

122. Maheswaran, D. Country of origin as a stereotype: Effects of consumer expertise and attribute strength on product evaluations. J. Consum. Res. 1994, 21, 354-365. [CrossRef]

123. Rahman, O.; Yu, H. A study of Canadian female baby boomers: Physiological and psychological needs, clothing choice and shopping motives. J. Fash. Mark. Manag. Int. J. 2018, 22, 509-526. [CrossRef]

124. Zafarmand, S.J.; Sugiyama, K.; Watanabe, M. Aesthetic and sustainability: The aesthetic attributes promoting product sustainability. J. Sustain. Prod. Des. 2006, 3, 173-186. [CrossRef]

125. KPMG. China's Connected Consumers: The Rise of the Millennials, 4th ed.; KPMG, 2017; p. 9. Available online: https://assets.kpmg/content/dam/kpmg/cn/pdf/en/2017/12/chinas-connected-consumers-the-riseof-the-millennials.pdf (accessed on 4 April 2020).

126. Wiedmann, K.-P.; Hennigs, N.; Langner, S. Spreading the word of fashion: Identifying social influencers in fashion marketing. J. Glob. Fash. Mark. 2012, 1, 142-153. [CrossRef]

127. Henninger, C.E.; Alevizou, P.J.; Oates, C.J. What is sustainable fashion? J. Fash. Mark. Manag. Int. J. 2016, 20, 400-416. [CrossRef]

128. Rahman, O.; Fung, B.C.M.; Chen, Z.; Gao, X. A cross-national study of apparel consumers' preferences and the role of product evaluative cues. Asia Pac. J. Mark. Logist. 2017, 29, 796-812. [CrossRef]

129. Tsoi, G. Wang Hong: China's Online Stars Making Real Cash. BBC News, 1 August 2016. Available online: https://www.bbc.com/news/world-asia-china-36802769 (accessed on 4 April 2020).

(C) 2020 by the authors. Licensee MDPI, Basel, Switzerland. This article is an open access article distributed under the terms and conditions of the Creative Commons Attribution (CC BY) license (http://creativecommons.org/licenses/by/4.0/). 